\title{
DINAMIKA POLITIK LOKAL PROVINSI RIAU DALAM SUKSESI KEMENANGAN ANNAS MAAMUN DAN ARSYADJULIANDI RACHMAN TAHUN 2013
}

\author{
Ahmad Saudi $^{1}$, Ricky Perianto ${ }^{2}$ \\ ${ }^{1}$ Ilmu Komunikasi, STISIP Persada Bunda \\ ahmadsaudi9145@gmail.com, rickyperianto@gmail.com
}

\begin{abstract}
This study aims to analyze how the dynamics of local politics in the succession of regional leadership in Riau Province by taking a case study of the victory of Annas Maamun and Arsyadjuliandi Rachman in the Riau Regional Head Election in 2013. This paper focuses on analyzing the factors causing the victory of Annas Maamun and Arsyadjuliandi Rachman from various political phenomena that occured in Riau Province. This research uses qualitative research methods and descriptive types. Data collection in this study uses literature study in which the authors take data from books, journals, documents, government sites that are relevant to this research. The results of this study indicate that there is a political dilemma among Riau's citizens who did not exercise their right to vote, the white group, so that Annas Maamun and Arsyadjuliandi Rachman were elected as Governor of Riau Province in 2013. Demands on the election results in Riau Province region from another candidate pair namely Herman Abdullah and Agus Widayat as the second winner showed that there was a dispute in the Election of Regional Heads of Riau Province.
\end{abstract}

Keywords: political dynamics, Riau Province, regional head election, abstentions

\begin{abstract}
Abstrak
Penelitian ini bertujuan untuk mengetahui bagaimana dinamika politik lokal dalam suksesi kepemimpinan kepala daerah di Provinsi Riau dengan mengambil studi kasus kemenangan Annas Maamun dan Arsyadjuliandi Rachman dalam Pemilihan Kepala Daerah Provinsi Riau Tahun 2013. Tulisan ini fokus untuk menganalisa faktor penyebab kemenangan Annas Maamun dan Arsyadjuliandi Rachman dari berbagai fenomena politik yang terjadi di Provinsi Riau. Penelitian ini menggunakan metode penelitian kualitatif dan jenis deskriptif. Pengumpulan data dalam penelitian ini menggunakan teknik studi literatur dimana penulis mengambil data dari buku, jurnal, dokumen, situs lembaga pemerintahan yang relevan terhadap penelitian ini. Hasil dari penelitian ini menunjukkan adanya dilematika politik yaitu banyaknya masyarakat yang tidak menggunakan hak pilihnya atau golongan putih, sehingga pasangan Annas Maamun dan Arsyadjuliandi Rachman terpilih sebagai Gubernur Provinsi Riau pada pemilihan kepala daerah di tahun 2013. Tuntutan hasil pemilihan kepala daaerah Provinsi Riau dari pasangan calon lain yaitu Herman Abdullah dan Agus Widayat sebagai pemenang kedua menjadi bukti adanya sengketa dalam Pemilihan Kepala Daerah Provinsi Riau.
\end{abstract}

Kata Kunci: dinamika politik, Provinsi Riau, pemilihan kepala daerah, golongan putih

\section{PENDAHULUAN}

Adanya pemilihan kepala daerah merupakan amanah langsung dari konstitusi bangsa ini. Tepat pada pasal 18 ayat 4 UUD 1945 dikatakan bahwa gubernur, 
bupati, dan walikota masing-masing sebagai kepala pemerintah daerah provinsi, kabupaten, dan kota dipilih secara demokratis. Hal ini lebih dasar lagi dikarenakan Indonesia pasca Orde Baru telah memilih untuk menjadikan negara Indonesia sebagai negara demokrasi. Atas keputusan ini disusunlah secara rinci mengenai pemilihan kepala daerah dengan disusunnya UndangUndang No. 32 Tahun 2004 tentang Pemerintahan Daerah dan berlaku sampai sekarang.

Demokrasi sebagai alasan diadakannya pemilihan kepala daerah diartikan sebagai pemerintahan yang dijalankan oleh rakyat, dan, untuk rakyat (Hamid 2006). J. Kristadi mengartikan demokrasi merupakan perbincangan tentang kekuasaan atau pengloaan kekuasaan secara beradab. Lebih lanjut Kristadi menganggap bahwa demokrasi lahir karena adanya kekuasaan yang lalim atau bersifat sentralistik, kemudian tumbuhlah nilai-nilai kehidupan yang lebih menghargai hak-hak individu, kesataraan, serta penghargaan terhadap hak manusia (Kristiadi 2008). Pada akhirnya demokrasi di Indonesia memberikan pengaruh yang besar terhadap desentralisasi. Dimana demokrasi memberi peluang besar bagi daerah untuk menjalankan otonominya. Otonomi diartikan sebagai keluasan dan kapasitas daerah untuk mengelola sendiri rumah tangganya (Sutoro 2004). Namun selama ini sebelum dipilihnya demokrasi sebagai bentuk pemerintahan di Indonesia, otonomi daerah hanya menjadi simbol belaka. Sebagaimana dijelaskan dalam UU No. 22 Tahun 1999 tentang Pemerintahan Daerah, kepala daerah sebagai orang yang memiliki kekuasaan untuk mengatur daerahnya dimandatkan langsung oleh pemerintahan pusat. Artinya otonomi secara luas yang dimaksudkan belum dapat dijalankan secara tepat.

Dilematika ini juga terjadi dengan diberlakukannya kekuasan daerah yang berasal dari pusat. Warsito Utomo menyatakan bahwa desentralisasi di Indonesia tidaklah tumbuh dari bawah, melainkan diberikan atau ditentukan oleh pemerintahan pusat secara bertingkat. Maksudnya dalam pemberian tugas kepada daerah, pemerintahan pusat pertama kali menyampaikan pada daerah tingkat I, lalu ke daerah tingkat II. Warsito menjelaskan bahwa keadaan ini memberi arti bahwa daerah tingkat II harus menunggu kerelaan daerah diatasnya dalam hal pemberian urusan-urusan pemerintahan. Semua itu tergantung pada seberapa besar kepentingan pemerintahan yang diatasnya terhadap urusan tersebut, jika besarnya kepentingan tersebut terhadap urusanurusan pemerintahan tersebut, maka urusan-urusan yang ada tidak akan didesentralisasikan (Warsito 1997).

Demokrasi akhirnya memberikan perubahan yang sangat signifikan. UU No. 22 Tahun 1999 di ubah menjadi UU No. 32 Tahun 2004. Atas dasar keputusan ini, desentralisasi dan otonomi daerah semakin mempertegas wewenangnya. Pusat tidak lagi mempertimbangkan pemberian urusan-urusan pemerintahan yang akan diserahkan ke daerah berdasarkan kepentingannya, melainkan telah adanya urusan yang tegas atas wewenang dari pemerintahan pusat dan pemerintahan daerah. Pembagian urusan ini telah dipertegas di dalam UU No. 32 Tahun 2004, dimana pemerintahan pusat memiliki wewenang dalam mengatasi urusan-urusan pemerintahan dalam bidang: (1) politik luar negeri; (2) pertahanan; (3) keamanan; (4) yustisi; (5) moneter dan fiskal nasional; (6) agama (Pasal 10 UU 32/2004). 
Sedangkan untuk daerah sendiri diberikan wewenang dalam mengatasi urusan pemerintahan pada bidang-bidang yang juga telah ditetapkan di dalam undang-undang, yakni: (1) perencanaan dan pengendalian pembangunan; (2) perencanaan, pemanfaatan, dan pengawasan tata ruang; (3) penyelenggaraan ketertiban umum dan ketentraman masyarakat; (4) penyediaan sarana dan prasarana umum; (5) penanganan bidang kesehatan; (6) penyelenggaraan pendidikan dan alokasi sumber daya manusia potensial; (7) penanggulangan masalah sosial lintas kabupaten/kota; (8) pelayanan bidang ketenagakerjaan lintas kabupaten/kota; (9) fasilitasi pengembangan koperasi, usaha kecil, dan menengah termasuk lintas kabupaten/kota; (10) pengendalian lingkungan hidup; (11) pelayanan pertanahan termasuk lintas kabupaten/kota; (12) pelayanan kependudukan, dan catatan sipil; (13) pelayanan administrasi umum pemerintahan; (14) pelayanan administrasi penanaman modal termasuk lintas kabupaten/kota; (15) penyelenggaraan pelayanan dasar lainnya yang belum dapat dilaksanakan oleh kabupaten/kota; dan (16) urusan wajib lainnya yang diamanatkan oleh peraturan perundang-undangan.

Selain adanya ketegasan dalam pembagian urusan pemerintahan pusat dan daerah, demokrasi member dampak dipilihnya kepala daerah secara langsung dan tidak lagi ditunjuk atau dimandatkan oleh pemerintah pusat. Melalui amandemen kedua terhadap pasal 18 UUD 1945 yang menyatakan bahwa gubernur, bupati, dan walikota masing-masing sebagai kepala pemerintah daerah provinsi, kabupaten, dan kota dipilih secara demokratis (Pasal 18 UUD 1945). Syarat, tata cara tentang pemilihan umum kepala daerah dibahas secara rinci pada pasal 56-74 UU No. 32/2004. Lebih detail tentang teknik pemilihan diatur kembali didalam UU No. 22 Tahun 2007 tentang penyelenggaraan pemilu, kemudian di ubah menajadi UU No. 15 Tahun 2011 tentang penyelenggaraan pemilu, dan akhirnya KPU mengeluarkan peraturan No. 9 Tahun 2012 tentang Pedoman Teknis Pencalonan Pemilihan Umum Kepala Daerah dan Wakil Kepala Daerah.

Dengan ditambahkannya ayat dalam pasal 18 UUD 1945 tentang Pemerintahan daerah yang memberi mandat bahwa kepala daerah dipilih secara demokratis, maka pada tahun 2005 untuk pertama kalinya amanah konstitusi tersebut dilaksanakan. Semua kepala daerah yang telah habis masa jabatannya harus dipilih melalui Pilkada. Pilkada bertujuan menjadikan pemerintahan daerah lebih demokratis (Budiarjo 2008).

Provinsi Riau sebagai salah satu provinsi terbesar di Indonesia dengan jumlah pendudukan dan luas wilayah, juga turut menjalankan amanah konstitusi tersebut. Yakni dengan memilih kepala daerah secara langsung pada tahun 2008 lalu. Lalu terpilihlah Rusli Zainal dengan masa jabatan sampai tahun 2013. Tepat tanggal 4 September 2013, diadakan lagi pemilihan kepala daerah. Namun cukup terjadi dilematika dalam proses tersebut. Dimana, Annas Maamun dan Arsyadjuliandi Rachman pasangan yang menang saat itu dinilai telah melakukan kecurangan. Akhirnya muncul berbagai gugatan dari calon Gubernur lain dan akhirnya dengan berbagai penundaan pada 27 November 2013 diadakan kembali Pilihan Gubernur Riau (Pilgubri) putaran kedua. Pada Pilgubri putaran kedua ini, AMAN singkatan pasangan Anas Maamun dan Arsyadjuliandi RaChman dinyatakan pemenang dengan suara sebesar 98.079 orang dengan persentase kemenangan sebesar 30,69\% dan golput sebesar 
46.97\%. Jika di analisa kembali angka golput jauh lebih tinggi di bandingkan jumlah pemilih pada pilgubri putaran kedua. Artinya masyarakat Riau masih menganggap menggunakan hak pilihnya bukanlah hal yang sangat penting. Berdasarkan latar belakang yang penulis sampaikan. Penulis sangat tertarik mengkaji lebih dalam lagi tentang dilematika yang terjadi saat suksesi kepemimpinan di Riau melalui pemilihan umum kepala daerah pada tahun 2013.

\section{STUDI TERDAHULU}

Gabriel Lele dalam jurnal ilmiahnya yang berjudul " The Paradox of Distance in Decentralized Indonesia" menyatakan efek adanya desentralisasi di Indonesia mengakibatkan adanya suatu pemerintahan daerah, namun apa yang terjadi sebenarnya tidak sesuai dengan apa yang dimaksudkan pada awal perumusan diberlakukannya desentralisasi. Menurut Gabriel, desentralisasi bertujuan mendekatkan masyarakat dengan pemerintah. Namun yang terjadi adalah hubungan anatar pemerintah-daerah dan masyarakat terlihat tidak memiliki kedekatan. Satu contoh yang diangkat oleh Gabriel adalah tidak ada jalan bagi masyarakat di daerah untuk meminta pertanggungjawaban terhadap pemerintah daerah yang telah lalai menjalankan tugasnya (Gabriel 2012).

Adanya pemerintahan daerah ini juga turut menghadirkan elit-elit lokal. menurut Haryanto dalam jurnal ilmiahnya yang berjudul "elit politik lokal dalam perubahan sistem politik" menjelaskan bahwa elit-elit politik lokal menduduki jabatan-jabatan strategis di pemerintahan lokal atau pemerintahan daerah. Lebih lanjut Haryanto menyatakan seorang individu dapat meraih dan menduduki posisi jabatan tersebut apabila yang bersangkutan mempunyai sumber daya sebagai basis dan mampu mengoptimalkannya sehingga pada gilirannya mengantarkannya sebagai elit politik lokal. Banyak faktor yang dapat mengantarkan seseorang menjadi elit politik lokal, salah satunya menurut Haryanto dengan sumber daya primordialisme atau tepatnya dengan penggunaan politik etnis (Haryanto 2009).

Realitanya penyelenggaraan pemerintahan daerah khususnya dalam proses suksesi kepemimpinan tidak dapat dihindari juga mengahadirkan dilematika. Masih banyak bermunculan masyarakat di daerah yang tidak terlibat langsung dalam proses suksesi kepemimpinan tersebut. Pada akhirnya masyarakat lebih memilih untuk tidak menggunakan hak pilihnya. Menurut Irmayani dalam jurnal ilmiahnya menyebutkan bahwa masyarakat yang tidak ikut memilih atau memberikan suaranya (golput) dapat dibagi menjadi dua kelompok. Kelompok pertama adalah orang-orang yang dengan kesadarannya tidak ingin memberikan suaranya dalam Pemilu. Kelompok kedua adalah orang-orang yang tidak memberikan suaranya karena berbagai faktor. Misalnya: Tidak terdaftar sebagai pemilih, pindah rumah tapi sudah terdaftar sebagai pemilih di tempat asal, merantau keluar daerah (sewaktu pemilu Tidak kembali), sudah meninggal dunia tetapi terdaftar sebagai pemilih dan sebagainya (Irmayanti 2015).

\section{TINJAUAN TEORITIS}

\section{Desentralisasi}


Hanif Nurcholis mengartikan desentralisasi adalah penyerahan wewenang politik dan administrasi dari puncak hirarki organisasi (pemerintah pusat) kepada jenjang organisasi di bawahnya (pemerintahan daerah). Pengertian ini dapat digambarkan sebagai berikut (Nurcholis 2005):

Gambar 1. Desentralisasi

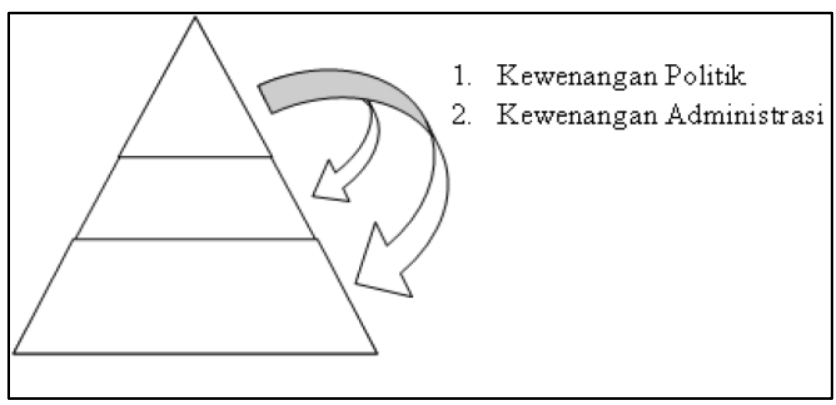

Desentralisasi memberikan bagian-bagian dalam cara pembagian tugas antara pemerintah pusat dengan pemerintah daerah. Diantaranya meliputi (Kaho 2012):

1) Sistem Residu, dimana sistem ini menegaskan penentuan tugas-tugas pemerintah pusat terlebih dahulu baru sisa dari tugas yang sudah diambil alih oleh pemerintah pusat diserahkan ke pemerintah daerah.

2) Sistem Material, sistem ini memiliki pengertian terbalik dengan sistem residu. Sistem material menekankan pada penentuan tugas pemerintah daerah yang ditetapkan terlebih dahulu, kemudian diluar tugas-tugas tersebut merupakan urusan pemerintah pusat.

3) Sistem Formal, sistem ini menjekaskan bahwa pemerintah daerah berhak mengurus urusan pemerintahan daerahnya tanpa diatur lebih jelas didalam perundang-undangan. Artinya, pemerintah daerah dapat mengurus segala sesuatu yang dianggap penting bagi daerahnya asal tidak mencakup urusan-urusan yang sudah diatur oleh pemerintah pusat atau pemerintah daerah diatasnya.

4) Sistem otonomi riil dan seluas-luasnya, dalam sistem ini penyerahan urusan-urusan kepala daerah didasarkan pada faktor yang nyata atau riil, sesuai kebutuhan dan kemampuan-kemampuan yang riil dari daerahdaerah maupun pemerintahan pusat.

Selanjutnya oleh Mariun dijelaskan bahwa desentralisasi memberikan efektivitas dalam pemerintahan. Secara umum Mariun menyatakan hal tersebut disebabkan kondisi wilayah suatu negara. Desentralisasi memberikan keefektivitas kepada negara yang di dalamnya terdapat berbagai daerah yang memiliki kekhasan khusus, adat istiadat, bahasa, kehidupan ekonomi iklim, flora fauna, tingkat pendidikan dan pengajaran yang berbeda-beda.

\section{Otonomi Daerah}

Otonomi diartikan sebagai hak, wewenang, dan kewajiban suatu pemerintahan daerah untuk mengatur dan mengurusi rumah tangganya sendiri (Inu Kencana 
2011). Otonomi daerah juga diartikan sebagai suatu hal yang penting dan bersifat mendasar, karena berhubungan dengan format desentralisasi dan kebijakan otonomi daerah itu sendiri. Tujuan dari adanya otonomi dibagi menjadi dua, yaitu tujuan umum dan tujuan khusus. Tujuan umum otonomi daerah ilah untuk meningkatkan kualitas keadilan, demokrasi, dan kesejahteraan bagi seluruh unsur bangsa yang beragam di dalam NKRI. Adapun yang mejadi tujuan khususnya meliputi (LIPI 2016):

1) Untuk meningkatkan keterlibatan dan partisipasi masyarakat dalam proses pembuatan keputusan maupun implementasinya sehingga terwujudnya pemerintahan lokal yang baik.

2) Memberikan pendidikan politik kepada masyarakat akan urgensi keterlibatan mereka dalam proses pemerintahan lokal.

3) Memberikan kesempatan bagi masyarakat untuk memilih para pemimpin mereka secara langsung.

4) Membangun kesaling-percayaan anatar masyarakat dan pemerintah.

\section{Demokrasi}

Pengertian demokrasi pada umumnya diketahui sebagai pemerintahan dari rakyat oleh rakyat untuk rakyat. Secara khususnya dapat diartikan dengan merujuk kepada beberapa ahli, yakni:

1) Abraham Lincoln berpendapat demokrasi adalah pemerintah dari, oleh, dan untuk rakyat.

2) Kranemburg berpendapat demokrasi berasal dari bahasa Yunani, yaitu demos (rakyat) dan cratein (memerintah). Jadi, demokrasi adalah cara memerintah dari rakyat.

3) Koentjoro Poerbopranoto berpendapat demokrasi adalah negara yang pemerintahannya dipegang oleh rakyat. Hal ini berarti suatu sistem di mana rakyat diikut sertakan dalam pemerintahan negara.

4) Harris Soche berpendapat demokrasi adalah pemerintahan rakyat karena itu kekuasaan melekat pada rakyat.

5) Henry B. Mayo berpendapat Sistem politik demokratis adalah menunjukkan kebijakan umum ditentukan atas dasar mayoritas oleh wakilwakil yang diawasi secara efektif oleh rakyat, dan didasarkan atas kesamaan politik dalam suasana terjaminnya kebebasan politik.

6) C.F. Strong menyatakan Suatu sistem pemerintahan pada mayoritas anggota dewasa dari masyarakat politik ikut serta atas dasar sistem perwakilan yang menjarnin bahwa pemerintah akhimya mempertanggungjawabkan tindakan kepada mayoritas.

7) Samuel Huntington menyatakan sistem politik sebagai demokratis sejauh para pembuat keputusan kolektif yang paling kuat dalam sistem itu dipilih melalui pemilihan umum yang adil, jujur, dan semua orang dewasa mempunyai hak yang sama memberikan suara.

\section{Kepemimpinan}

Paul Hersey dan Banchart menyatakan bahwa Kepemimpinan adalah sebagai berikut (Tim Pengembang IImu Pendidikan 2007): 
1) Leadership is the activity of influencing exercised to strive willingly for group objectives.

2) Leadership as interpersonal influence exercised in situation an directed, through thr communication process, toward the attainment of a specialized goal the goals.

3) Leadership is influencing people to follow in the achievement of a common goal.

Menurut Hrmhiel and Coons bahwa kepemimpinan adalah perilaku dari seorang individu yang memimpin aktivitas-aktivitas suatu kelompok ke suatu kelompok ke suatu tujuan yang akan dicapai . Sedangkan menurut Rauch dan Behling, kepemimpinan adalah proses mempengaruhi aktivitas-aktivitas sebuah kelompok yang diorganisasikan kearah pencapaian tujuan. Jacobs dan Jacques mengartikan bahwa kepemimpinan merupakan sebuah proses memberikan arti terhadap usaha kolektif, dan yang mengakibatkan kesediaan untuk melakukan usaha yang diinginkan untuk mencapai sasaran. Lebih lanjut ditegaskan oleh Kouzes dan Ponser bahwa kepemimpinan ialah hubungan antara anggotaanggota dan pemimpin yang berlangsung atas dasar saling membutuhkan dan minat yang sama dalam rangka mencapai tujuan (Tim Pengembang IImu Pendidikan 2007).

\section{Elit Lokal}

Menurut Heryanto yang dimaksud elit lokal adalah mereka yang menduduki posisi jabatan politik di ranah lokal. Perjalanan sejarah mencatat bahwa posisi mereka sebagai elit politik lokal mengalami 'pasang naik' dan 'pasang surut' paralel dengan perubahan yang terjadi. Mereka yang pada rentang waktu tertentu mengalami pembatasan dari struktur yang ada, berubah nasibnya menjadi mengalami pemberdayaan pada kurun waktu yang lain. Demikian pula ada di antara mereka yang semula mengalami pemberdayaan berubah menjadi mengalami pembatasan dari struktur (Heryanto 2009).

\section{Politik Etnis}

Pendefinisian politik etnis dapat diartikan dari asal kata tersebut. Politik menurut Miriam Budiardjo dapat diartikan sebagai kekuasaan, pengambilan keputusan, kebijakan public, dan alokasi atau distribusi (Miriam Budiarjo 2008). Sedangkan etnis menurut Heryanto dapat dipahami sebagai sekumpulan orang (penduduk) yang berasal dari keturunan sama, mempunyai latar belakang sejarah dan budaya sama, dan bertempat tinggal dalam kelompok pada teritori tertentu. Mereka mempunyai solidaritas kelompok yang kuat dan mempunyai kesadaran terhadap kepentingan bersama. Sementara itu, etnisitas mengacu bukan pada 'property' kelompok, namun lebih merujuk pada aspek yang berhubungan atau berkaitan dengan etnis. Etnisitas merujuk pada konsep relasional yang mendasarkan pada pengkategorian kumpulan orang yang membentuk dan dibentuk oleh kolektivitas (Heryanto 2009). 


\section{Partisipasi Politik}

Perilaku politik seseorang dapat dilihat dari bentuk partisipasi politik yang dilakukannya. Bentuk partisipasi dilihat dari segi kegiatan dibagi menjadi dua, yaitu (Sudijono 1995):

1) Partisipasi aktif, yaitu bentuk partisipasi ini berorientasi kepada segi masukan dan keluaran suatu sistem politik. Misalnya, kegiatan warga negara mengajukan usul mengenai suatu kebijakana umum, mengajukan alternatif kebijakan umum yang berbeda dengan kebijakan pemerintah, mengajukan kritik dan saran perbaikan untuk meluruskan kebijaksanaan, membayar pajak, dan ikut serta dalam kegiatan pemilihan pimpinan pemerintahan.

2) Partisipasi Pasif, yaitu bentuk partisipasi ini berorientasi kepada segi keluaran suatu sistem politik. Misalnya, kegiatan mentaati peraturan atau perintah, menerima, dan melaksanakan begitu saja setiap keputusan pemerintah.

Menurut Rosenberg ada 3 alasan mengapa orang enggan sekali berpartisipasi politik, Pertama bahwa individu memandang aktivitas politik merupakan ancaman terhadap beberapa aspek kehidupannya. la beranggapan bahwa mengikuti kegiatan politik dapat merusak hubungan sosial, dengan lawannya dan dengan pekerjaannya karena kedekatannya dengan partaipartai politik tertentu. Kedua, bahwa konsekuensi yang ditanggung dari suatu aktivitas politik mereka sebagai pekerjaan sia-sia. Mungkin disini individu merasa adanya jurang pemisah antara cita-citanya dengan realitas politik. Karena jurang pemisah begitu besarnya sehingga dianggap tiada lagi aktifitas politik yang kiranya dapat menjembatani. Ketiga, beranggapan bahwa memacu diri untuk tidak terlibat atau sebagai perangsang politik adalah sebagai faktor yang sangat penting untuk mendorong aktifitas politik (Sudijono 1995).

\section{METODE PENELITIAN}

Penelitian ini menggunakan metode kualitatif dengan jenis deskriptif analisis. Teknik pengumpulan data menggunakan studi literatur yaitu penulis mengumpulkan data dari berbagai sumber seperti buku, jurnal, dokumen, situs pemerintahan serta media online yang relevan dengan penelitian ini.

\section{PEMBAHASAN}

\section{Analisis Suksesi Kepemimpinan di Provinsi Riau}

Sesuai dengan situasi pemerintahan daerah di Indonesia yang pada sejarahnya telah jatuh bangun dalam memilih antara penerapan sentralisasi dan desentralisasi, lalu pada akhirnya Indonesia telah siap memilih untuk menerapkan sistem pemerintahan daerah dengan desentralisasi. Akibatnya muncul berbagai dampak, yakni adanya otonomi daerah yang diartikan oleh Inu 
Kencana sebagai hak, wewenang, dan kewajiban suatu pemerintahan daerah untuk mengatur dan mengurusi rumah tangganya sendiri. Kemudian setelah runtuhnya masa orde baru Indonesia semakin mantap untuk menetapkan bentuk negara yang bersifat demokratis.

Keputusan itu berakibat langsung terhadap situasi dan kondisi di pemerintahan daerah. Dibentuklah peraturan perundang-undangan dengan No. 22 Tahun 1999 tentang Pemerintahan Daerah yang keseluruhan isinya lebih rinci dari peraturan-peraturan pemerintahan daerah sebelumnya. Semakin tahun semakin mantapnya bangsa Indonesia menjalankan demokrasi, lalu pada tahun 2004 undang-undang tentang pemerintahan daerah kembali direvisi. Undang-undang tersebut yaitu UU No.32/2004 tentang Pemerintahan Daerah. Di dalam UU ini ditambahkan dengan mekanisme pemilihan kepala daerah. Ada beberapa kriteria baik dalam calon dan pelaksana pemilihan tersebut yang cukup jelas di sebutkan di dalam pasal 56-74 UU No. 32/2004. Lalu pada tahun 2005 untuk pertama kalinya pemerintah daerah melakukan pemilihan umum kepala daerah yang sebelumnya dipilih oleh DPRD Provinsi.

Sampai pada akhirnya semua daerah aktif memilih kepala daerah secara langsung sampai saat ini. Pelaksanaannya yang masih berjalan dua kali, muncul berbagai dilematika, diantaranya meliputi partisipasi masyarakat di daerah yang cukup rendah lalu pada akhirnya dibuat pemilihan putaran kedua yang pastinya menambah anggaran yang sangat banyak. Selain itu muncul dilematika tersebut yang datang dari peserta pilkada dari incumbent yang terindikasi lahir karena adanya dorongan secara etnis.

Dilematika-dilematika tersebut juga terjadi di Provinsi Riau. Tepat 4 September 2013 lalu, Provinsi Riau telah melaksanakan pemilihan umum kepala daerah. Pesta demokrasi ini banyak melibatkan berbagai aliansi khususnya masyarakat di Provinsi Riau yang berperan aktif memilih calon Pilkada yang telah ditetapkan KPUD Provinsi Riau. KPUD Provinsi Riau menetapkan sebanyak 5 calon gubernur Riau yang akan melaksanakan kontestasi pada tanggal 4 September. Kelima calon tersebut ialah:

Tabel 1. Pasangan Calon Gubernur Riau

\begin{tabular}{|c|l|l|}
\hline No. & \multicolumn{1}{|c|}{ Nama Pasangan } & \multicolumn{1}{c|}{ Pendukung } \\
\hline 1 & Herman Abdullah-Agus Widayat & Belasan partai non parlemen \\
\hline 2 & Anas Maamun-Arsyadjuliandi Rahman & Golkar \\
\hline 3 & Lukman Edi-Suryadi Khusaini & PKB dan PDIP \\
\hline 4 & Achmad-Masrul Kasmy & Demokrat dan PBR \\
\hline 5 & Jon Erizal-Mambang Mit & PAN dan PKS \\
\hline
\end{tabular}

Sumber: Detik.com

Berbagai masyarakat disetiap Kabupaten/Kota terdata memiliki hak suara untuk melakukan pemilihan kepala daerah tersebut. Berdasarkan data dari KPUD Provinsi Riau sebanyak 4.000.459 orang masyarakat Riau yang memiliki hak pilih. Perincian setiap daerah dapat dilihat pada table berikut:

Tabel 2. Rekapitulasi Jumlah Pemilih Terdaftar KPUD Provinsi Riau Tahun 2013

\begin{tabular}{|l|l|l|}
\hline NO & KABUPATEN/KOTA & PEMILIH TERDAFTAR \\
\hline
\end{tabular}


Jurnal Dinamika Pemerintahan

Vol.3, No. 2 (Agustus 2020)

doi: https://doi.org/10.36341/jdp.v3i2.1370

\begin{tabular}{|c|l|l|l|l|}
\hline & & \multicolumn{1}{c|}{ LK } & \multicolumn{1}{c|}{ PR } & \multicolumn{1}{c|}{ JUMLAH } \\
\hline 1 & KAMPAR & 266.397 & 251.553 & 517.950 \\
\hline 2 & INHU & 136.301 & 128.199 & 264.500 \\
\hline 3 & BENGKALIS & 186.277 & 174.098 & 360.371 \\
\hline 4 & INHIL & 256.856 & 234.891 & 491.747 \\
\hline 5 & PELALAWAN & 119.243 & 109.089 & 228.332 \\
\hline 6 & ROHUL & 168.878 & 159.742 & 328.620 \\
\hline 7 & ROHIL & 216.306 & 204.538 & 420.844 \\
\hline 8 & SIAK & 127.916 & 131.141 & 259.057 \\
\hline 9 & KUANSING & 114.004 & 109.094 & 223.098 \\
\hline 10 & MERANTI & 70.737 & 66.155 & 136.892 \\
\hline 11 & PEKANBARU & 295.411 & 292.068 & 587.479 \\
\hline 12 & DUMAI & 93.317 & 88.252 & 181.569 \\
\hline \multicolumn{2}{|c|}{ JUMLAH } & 2.051 .643 & 1.948 .816 & 4.000 .459 \\
\hline
\end{tabular}

Sumber: KPUD Provinsi Riau

Hasil dari pemilihan tersebut disampaikan oleh KPUD Provinsi Riau dimenangkan oleh Pasangan Nomor urut 2 Anas Maamun-Arsyadjuliandi Rachman dengan jumlah pemilih sebesar 685.291 orang dari 4.000.459 jumlah pemilih yang ditetapkan KPUD Provinsi Riau dan dari 2.376.839 suara yang sah. Jika dipersentasikan kemenangan Anas Maamun-Arsyadjuliandi Rachman mencapai $17 \%$ dari jumlah pemilih dan $28.8 \%$ dari jumlah suara yang sah. Rincian rekapitulasi jumlah pemilih yang sah pada setiap calon dapat dilihat di table berikut:

Tabel 3. Rekapitulasi Hasil Perhitungan Suara Pemilihan Gubernur dan Wakil Gubernur Provinsi Riau Tahun 2013

\begin{tabular}{|c|c|c|c|c|c|c|c|c|c|c|c|c|c|c|}
\hline \multirow{2}{*}{ No } & \multirow{2}{*}{$\begin{array}{l}\text { NAMA PASANGAN CALON GUBERNUR DAN } \\
\text { WAKL GUBERNUR RLAU TAHUN 2013 }\end{array}$} & \multicolumn{12}{|c|}{ PEROLEHAN SUARA UNTUK PASANGAN CALON GUBERNUR DAN WAKL GUBERNUR RIAU TAHUN 213} & \multirow{2}{*}{$\begin{array}{l}\text { JUMLLA AKHIR } \\
\text { PNDAHKAN }\end{array}$} \\
\hline & & $\begin{array}{c}\text { Kota } \\
\text { Pekanbaru }\end{array}$ & Kab. Kampar & $\begin{array}{c}\text { Kab. Rolan } \\
\text { Hulu }\end{array}$ & $\begin{array}{c}\text { Kab. Rokan } \\
\text { Hilir }\end{array}$ & Kota Dumai & $\begin{array}{c}\text { Kab. } \\
\text { Bengkalis }\end{array}$ & $\begin{array}{l}\text { Kabb. Kep. } \\
\text { Meranti }\end{array}$ & Kab. Siak & $\begin{array}{c}\text { Kab. } \\
\text { Pelalawan }\end{array}$ & $\begin{array}{c}\text { Kab. Intragin } \\
\text { Nhilir }\end{array}$ & $\begin{array}{c}\text { Kab. Indragini } \\
\text { Hulu }\end{array}$ & \begin{tabular}{|c} 
Kab. Kunantan \\
Singingi
\end{tabular} & \\
\hline 1 & 2 & 3 & 4 & 5 & 6 & 7 & 8 & 9 & 10 & 11 & 12 & 13 & 14 & 15 \\
\hline 1 & $\begin{array}{l}\text { Drs. H. HERUANABBOULAH, MM } \\
\text { DAN } \\
\text { dt.H.AGUSWDAYAT, MM }\end{array}$ & 148,225 & 159,380 & 17,986 & 8,964 & 26,885 & 20,998 & 11,711 & 25220 & 17,849 & 420 & 14,008 & 57,659 & 546,714 \\
\hline 2 & $\begin{array}{c}\text { H.ANNAS } \\
\text { DAN } \\
\text { It. H. APSYADJULANDI RACHMAN, MBA }\end{array}$ & 41,50 & 22,982 & 34289 & 278,933 & 30,818 & 80,461 & 14,278 & 4,574 & 41,003 & 40215 & 26,054 & 17,110 & 685291 \\
\hline 3 & $\begin{array}{l}\text { 1. H.MUHAMAD LUKUAN EDY, M.S } \\
\text { DAN } \\
\text { H. SURYAO KHUSANN, S.SOS, MM }\end{array}$ & 29,333 & 30,003 & 12,027 & 15,05 & 10,455 & 23,030 & 9,649 & 20,555 & 22,755 & 116,987 & 24,26 & 17,898 & 333,621 \\
\hline 4 & $\begin{array}{c}\text { Ds. H. ACHMAD,M.Si } \\
\text { DAN } \\
\text { Ds. H. MASRUL KASUY, MSI }\end{array}$ & 36,010 & 40,851 & 167,152 & 12,603 & 13998 & 26,778 & 30,899 & 20,405 & 19,650 & Q2,035 & 22,06 & 36,53 & 428,665 \\
\hline 5 & $\begin{array}{l}\text { H. JONERZZAL, SE, NBA } \\
\text { DAN } \\
\text { Drs. H.R. MAMBANG MT }\end{array}$ & 53,018 & 29,598 & 11,670 & 5,519 & 16,434 & 60,19 & 13,597 & 20,390 & 18,288 & 28,37 & 41,092 & 9,053 & 318,548 \\
\hline & & SUAR & AH UNTUK & UHAPAS & ICALON & JBERNUAD & WAKLL GU & IRRILU & & & & & & $2,376,839$ \\
\hline
\end{tabular}

Sumber: KPUD Provinsi Riau

Hasil Pemilukada tersebut dapat dihitung jumlah masyarakat Riau yang tidak menggunakan hak pilihnya. Berdasarkan data dari KPUD jumlah suara sah sebesar 2.376.839 dan jumlah suara tidak sah sebesar 75.730. Jika ditambahkan, berarti sebesar 2.452 .569 masyarakat Riau yang telah menggunakan hak pilihnya. Berarti sebanyak 1.547 .890 orang Masyarakat Riau yang tidak menggunakan hak pilihnya. Dalam bentuk persentase berarti sebesar $61.3 \%$ masyarakat Riau yang tidak menggunakan hak pilihnya. Secara 
Jurnal Dinamika Pemerintahan

Vol.3, No. 2 (Agustus 2020)

doi: https://doi.org/10.36341/jdp.v3i2.1370

umum presentase rekapitulasi perhitungan suara pilgubri dapat dilihat pada table berikut:

Tabel 4. Persentase Rekapitulasi Hasil Perhitungan Suara Pemilihan Gubernur dan Wakil Gubernur Provinsi Riau Tahun 2013

\begin{tabular}{|c|l|l|}
\hline NO & \multicolumn{1}{|c|}{ PASANGAN } & \multicolumn{1}{|c|}{ Jumlah Suara (\%) } \\
\hline 1 & Herman-Agus & 23.00 \\
\hline 2 & Anas-Andi & 28.83 \\
\hline 3 & Lukman Edi-Suryadi & 14.04 \\
\hline 4 & Achmad-Masrul & 20.73 \\
\hline 5 & Jon Erizal-Mambang Mit Jumlah suara sah & 13.40 \\
\hline \multicolumn{2}{r}{ Jumlah suara tidak sah } & 75.730 .839 suara \\
\hline
\end{tabular}

Sumber: KPUD Provinsi Riau

Berdasarkan Peraturan Perundang-undangan tepatnya pada pasal 107 Undang-undang No. 12 Tahun 2008 Tentang Pemilihan Umum, bahwa jika perolehan penghitungan suara kepala daerah tertinggi tidak mencapai $30 \%$ maka harus dilakukan pemilihan putaran kedua. Hal yang paling cukup disayangkan karena banyaknya masyarakat Riau yang tidak menggunakan hak suaranya. Dalam perjalanannya, pasangan nomor urut 1 Herman AbdullahAgus Widayat, menyatakan keberatannya atas kemenangan Anas MaamunArsyadjuliandi Rahman. Atas kemenangan tersebut Herman Abdullah-Agus Widayat sebagai pemenang kedua mengajukan gugatan ke MA dengan berbagai gugatan, yakni:

1) Termohon dan jajarannya melakukan pelanggaran terstruktur, sistematis, dan masif di Kabupaten Rokan Hilir (Permohonan Perkara Nomor 189/PHPU.D-XI/2013 Tentang Perselisihan Hasil Pemilihan Umum Kepala Daerah dan Wakil Kepala Daerah Provinsi Riau), yaitu:

a) Menghalangi saksi-saksi pemohon untuk mendapatkan form model C.1-KWK-KPU;

b) Mengantar Surat Undangan Memilih dengan di tempel kartu nama pasangan calon nomor urut 2;

c) Melakukan pencoblosan surat suara untuk pasangan calon nomor urut 2 berulang kali;

d) Tidak mengundang saksi pihak pemohon pada waktu pleno di KPU Rokan Hilir, hari minggu, tanggal 1 Desember 2013;

e) Bersikap tidak independen dengan menyebut kata-kata AMAN waktu pemilih masuk ke TPS sementara kata AMAN itu adalah simbol dari singkatan pasangan calon nomor urut 2.

2) Termohon dan jajarannya melakukan pelanggaran terstruktur, sistematis dan masif di Kabupaten Rokan Hulu, yaitu salah seorang anggota KPPS mencoblos dan memasukkan surat suara lebih dari 10 lembar ke dalam kotak suara;

3) Termohon melakukan pelanggaran terstruktur, sistematis, dan masif di Kabupaten Siak yaitu Panitia Pengawas Pemilu Kecamatan Koto Gasib menyurati tim Pemohon menganjurkan semua baliho yang ada di kawasan Koto Gasib agar diturunkan, sementara kami sudah 
menurunkan sebelum hari tenang yaitu tanggal $23 \mathrm{~s} / \mathrm{d} 26$ November 2013, akan tetapi baliho dan banner nomor urut 2 pada lokasi yang sama tidak diturunkan;

4) Termohon melakukan pelanggaran terstruktur, sistematis dan masif di Kabupaten Kepulauan Meranti, yaitu petugas KPPS menyampaikan kepada pemilih/penerima undangan kalau memilih calon nomor urut 2 maka akan mendapatkan rumah sesuai dengan yang ada pada gambar kartu nama cara mencoblos;

5) Termohon melakukan pelanggaran terstruktur, sistematis dan masif di Kota Dumai, yaitu KPU Kabupaten Rokan Hilir menempatkan TPS di wilayah hukum Kota Dumai yaitu TPS 003 di Teluk Dalam Dumai dan TPS 004 di Sungai Senipis Dumai, Kelurahan Batu Teritip, Kecamatan Sungai Sembilan Kota Dumai. Kedua TPS tersebut pemilinnya di mobilisasi dari Rokan Hilir;

6) Panwaslukada Provinsi Riau beserta jajarannya juga tidak menggunakan kewenangannya secara maksimal untuk melakukan penindakan atas pelanggaran pelanggaran yang terjadi sepanjang pemilukada Provinsi Riau Tahun 2013 Putaran Kedua;

7) Pihak terkait yakni pasangan calon nomor urut 2 atas nama Annas dan ArsyadJuliandi Rachman, selaku salah satu pasangan calon peserta pemilukada Provinsi Riau putaran kedua memperoleh hasil suara demikian tidak terlepas dari prakek kecurangan yang juga bersifat terstruktur, sistematis dan masif. Pelanggaran terstruktur sistematis dan massif yang dilakukan oleh pihak terkait tersebar di sepuluh kabupaten dan satu kota se-Provinsi Riau, yaitu berupa politik uang, mengajak perangkat daerah/PNS/guru untuk memilihnya, serta melakukan kampanye di masa tenang.

Atas gugatan yang dilakukan oleh Herman Abdullah-Agus Widayat dan akhirnya diterima oleh MK, dapat diperhatikan bahwa kemenangan Anas Maamun-Arsyadjuliandi Rachman diindikasi karena adanya politik etnis. Annas saat mencalonkan diri sebagai calon Gubernur Riau merupakan Bupati Rokan Hilir dan suara Annas Maamun-Arsyadjuliandi Rachman di Rohil paling tinggi yakni sebesar 278.933 pemilih. Dibandingkan daerah lain Annas MaamunArsyadjuliandi Rachman hanya memperoleh suara tidak sampai 90.000 pemilih. Dilanjutkan yang terbesar kedua oleh pasangan nomor urut 1 Herman Abdullah-Agus Widayat dengan jumlah pemilih 153.380 di Kabupaten Kampar.

Dua faktor tersebut mengakibatkan KPUD kembali mengadapakan pemilihan gubernur Provinsi Riau putasarn kedua. Berdasarkan UU No.12/2008 pada putaran kedua hanya diikuti oleh pasangan pemenangan pertama dan pemenangan kedua, sudah pasti yang akan kembali berlaga pada pemilihan gubernur Riau yaitu pasangan nomor urut 2 dan 1 yaitu Annas MaamunArsyadjuliandi Rachman dan Herman Abdullah-Agus Widayat. KPUD menetapkan pemilihan Gubernur Riau tersebut pada 27 November 2013. Dengan jumlah pemilih yang tetap, maka diperolehlah hasil penghitungan suara yang kembali memenangkan Annas Maamun-Arsyadjuliandi Rachman. Dengan perolehan suara sebagai berikut: 
Jurnal Dinamika Pemerintahan

Vol.3, No. 2 (Agustus 2020)

doi: https://doi.org/10.36341/jdp.v3i2.1370

Tabel 5. Rekapitulasi Hasil Perhitungan Suara Putaran Kedua Pemilihan

Gubernur dan Wakil Gubernur Provinsi Riau Tahun 2013

\begin{tabular}{|c|c|c|c|c|c|c|c|c|c|}
\hline \multirow[b]{2}{*}{ No } & & JTIL.HH & JUIL_HH & \multirow{2}{*}{$\begin{array}{l}\text { TOTALSEARA } \\
\text { ILASCK }\end{array}$} & \multicolumn{3}{|c|}{ SAIVPEL GOLPUT PROSENTASE } & \multicolumn{2}{|l|}{ PROSENTASE } \\
\hline & KABLPATEN & SCARA PEYILIH & SCARA PE.IILIH & & & & JCMLAH SCARA & JTMLAHSCARA & GOLPCT \\
\hline & & NotRUT(1) & N0 TRUT (2) & & & & N0 LRLT(1) & NotRUT (2) & \\
\hline & 1 KAIMPAR & 17388 & 5405 & 22793 & 41602 & 18809 & $41.80 \%$ & $12.99 \%$ & $45.21 \%$ \\
\hline & $2 \mathbb{N H U}$ & 2441 & 4227 & 6668 & 21533 & 14865 & $11.34 \%$ & $19.63 \%$ & $69.03 \%$ \\
\hline & 3 BENGK_LIS & 4298 & 8163 & 12451 & 25310 & 13059 & $16.85 \%$ & $31.96 \%$ & $51.19 \%$ \\
\hline & 4 INHIL & 7807 & 12411 & 20218 & 38402 & 18184 & $20.33 \%$ & $32.32 \%$ & $47.35 \%$ \\
\hline & 5PELELAIVAN & 3002 & 5098 & 8100 & 15941 & 7841 & $18.83 \%$ & $31.98 \%$ & $49.19 \%$ \\
\hline & 6ROHLI & 4741 & 12440 & 16981 & 22832 & 5851 & $20.76 \%$ & $53.61 \%$ & $25.63 \%$ \\
\hline & 7ROHL & 1471 & 21329 & 22800 & 32064 & 9264 & $4.59 \%$ & $66.52 \%$ & $28.89 \%$ \\
\hline & 8 S SLAK & 4973 & 5765 & 10738 & 28002 & 17264 & $17.76 \%$ & $20.69 \%$ & $61.65 \%$ \\
\hline & 9 KUANSAGG & 5336 & 5205 & 10541 & 19200 & 8659 & $27.79 \%$ & $27.11 \%$ & $45.10 \%$ \\
\hline & 10 NERALIII & 1669 & 3441 & 5110 & 8871 & 3761 & $18.81 \%$ & $38.79 \%$ & $42.40 \%$ \\
\hline & 11 PEKANBARU & 14836 & 10949 & 25785 & 49665 & 23880 & $29.87 \%$ & $22.05 \%$ & $48.08 \%$ \\
\hline & 12 DUMAI & 3451 & 3856 & 7307 & 15999 & 8692 & $21.57 \%$ & $24.10 \%$ & $54.33 \%$ \\
\hline & $\begin{array}{l}\text { TOTAL } \\
\text { SUARA }\end{array}$ & 71413 & 98079 & 169492 & 319621 & 150129 & $22.34 \%$ & $30.69 \%$ & $46.97 \%$ \\
\hline
\end{tabular}

Sumber: Asosiasi IImu Politik Indonesia FISIP UR

Dari data yang sudah sangat lengkap oleh AIPI FISIP UR dapat kembali ditegaskan bahwa masyarakat Riau yang tidak menggunakan hak pilihnya masih cukup tinggi. Walaupun memang adanya penurunan jumlah dari pemilihan sebelumnya. Banyak indikator yang dapat disimpulkan tentang alasan masyarakat Riau tidak menggunakan hak pilihnya. Berdasarkan pendapat dari Gabriel Lele bahwa adanya hubungan yang tidak erat antara pemerintah daerah dengan masyarakat. Pada akhirnya hal ini bisa dikatakan sebagai alasan masih banyak masyarakat Riau yang tidak mau menggunakan hak pilihnya. Contoh yang dikatakan oleh Gabriel Lele ialah tidak terciptanya pengawasan yang baik untuk menegur Pemerintah apabila Pemerintah salah. Pernyataan Gabriel Lele jika dibawa dengan keadaan di Riau cukup relevan. Dimana adanya perperangan saling sahut-menyahut antara masyarakat lewat LSM untuk menyampaikan aspirasinya ke Pemerintah.

Irmayani juga mengatakan menyebutkan bahwa masyarakat yang tidak menggunakan hak pilihnya dapat dibagi menjadi dua kelompok. Kelompok pertama adalah orang-orang yang dengan kesadarannya tidak ingin memberikan suaranya dalam Pemilu. Kelompok kedua adalah orang-orang yang tidak memberikan suaranya karena berbagai faktor. Misalnya: tidak terdaftar sebagai pemilih, pindah rumah tapi sudah terdaftar sebagai pemilih di tempat asal, merantau keluar daerah (sewaktu pemilu tidak kembali), sudah meninggal dunia tetapi terdaftar sebagai pemilih dan sebagainya. Hal ini terjadi di mayasrakat Provinsi Riau banyak faktor yang mendasari untuk tidak menggunakan hak pilihnya sehingga menjadikan penyebab kemenangan pasangan Annas dan Arsyadjuliandi Rachman pada pemilihan kepala daerah provinsi riau tahun 2013. 


\section{KESIMPULAN}

Pada dasarnya desentralisasi telah mengantarkan bangsa Indonesia kepada otonomi daerah kemudian dengan mantapnya Indonesia memilih demokrasi sebagai bentuk negara Indonesia pasca orde baru. Konsekuensi dari hal ini ialah Indonesia diadakannya pemilihan kepala gubernur di setiap daerah di Provinsi Riau. Sama halnya di Riau, banyak dilematika dalam suksesi kepemimpinan di Riau. Diantaranya golput yang besar, gugatan yang dilakukan oleh pasangan Herman Abdullah-Agus Widayat ke MK atas kecurangankecurangan yang dilakukan Annas Maamun-Arsyadjuliandi Rachman pada putaran pertama dan menjadikan mereka menang. Gugatan tersebut diterima lalu pada akhirnya diadakan putaran kedua tanggal 27 November 2013.

\section{REFERENSI}

Basyaib, Hamid. 2006. Membela kebebasan: percakapan tentang demokrasi liberal. Jakarta: Pustaka Alvabet.

Budiardjo, Miriam. Dasar-dasar ilmu Politik. Jakarta: Gramedia Pustaka Utama, 2008).

Eko, Sutoro. 2004. Reformasi Politik dan Pemberdayaan Masyarakat. Yogyakarta: APMD Press.

Haryanto. 2009. "Elit Politik Lokal Dalam Perubahan Sistem Politik". Jurnal IImu Sosial Dan Ilmu Politik. No. 2. Vol. 13: 131-148.

Irmayani. 2005. "Melihat Partisipasi Masyarakat Langkat Pada Pemilu 2004". Jurnal Wawasan. No. 1. Vol. 11: 10-15

Kaho. J.R. 2012. Analisis Hubungan Pemerintah Pusat Dan Daerah Di Indonesia. Yogyakarta: PolGov.

Kristiadi, J. 2008. Demokrasi dan Etika Bernegara. Yogyakarta: Kanisius.

Lele, Gabriel. 2012. "The Paradox Of Distance In Decentralized Indonesia". Jurnal IImu Sosial Dan IImu Politik. No. 3. Vol. 15.

LIPI. 2006. Membangun Format Baru Otonomi Daerah. Jakarta: LIPI Press.

Nurcholis, Hanif. 2005. Teori Dan Praktik Pemerintahan Dan Otonomi Daerah. Jakarta: Gramedia Widiasarana.

Pasal 18 Undang-Undang Dasar 1945

Pasal 10 Undang-Undang Nomor 32 Tahun 2004 tentang Pemerintahan Daerah

Permohonan Perkara Nomor 189/PHPU.D-XI/2013 Tentang Perselisihan Hasil Pemilihan Umum Kepala Daerah Dan Wakil Kepala Daerah Provinsi Riau.

Pengertian ahli. 2013. Pengertian demokrasi menurut para ahli. http://www.pengertianahli.com/2013/05/pengertian-demokrasi-menurutpara-ahli.html.

Sudijono, Sastroadmojo, Perilaku Politik, IKIP Semarang Press, 1995.

Syafi'I, Inu Kencana. 2011. Sistem Pemerintahan Indonesia. Jakarta: PT Rineka Cipt.

Tim Pengembang IImu Pendidikan. 2007. IImu dan Aplikasi Pendidikan. Jakarta: PT IMTIMA. 
Jurnal Dinamika Pemerintahan

Vol.3, No. 2 (Agustus 2020)

doi: https://doi.org/10.36341/jdp.v3i2.1370

Utomo, Warsito. 1997. "Peran Dan Strategi Peningkatan PAD dalam otonomi

Daerah". Jurnal Sosial Politik. Vol. 1. No. 1: 98-115. 